\title{
Total phenolic and flavonoid contents of n-hexane fraction in binjai leaves (Mangifera caesia Jack. ex. Wall)
}

\section{Kadar total fenolik dan flavonoid fraksi n-heksan daun binjai (Mangifera caesia Jack. ex. Wall)}

\author{
Cahaya Rahayu Yuliani¹, Hafiz Ramadhan ${ }^{1 *}$, Putri Indah Sayakti ${ }^{1}$, Cast Torizellia ${ }^{1}$
}

${ }^{1}$ Sekolah Tinggi Ilmu Kesehatan Borneo Lestari, Banjarbaru, Indonesia

*Corresponding author: hafizramadhan14@gmail.com

\begin{abstract}
Background: Binjai leaves (Mangifera caesia Jack. ex. Wall) or M. caesia contain phenolic and flavonoid compounds important in medicinal plants development. The solvent difference and fractionation will give various active substance concentrations.

Objective: To evaluate the phenolic and flavonoid content qualitatively and quantitatively from the nhexane fraction of binjai leaves methanol extract.

Methods: The soxhletation method with methanol was used to extract binjai leaves followed by fractionation. Thin Layer Chromatography (TLC) followed by spraying reagents were used to test phenols and flavonoids compounds. Folin-Ciocalteu reagents were used to analyzed total phenolics, while $\mathrm{AlCl}_{3}$ reagents were used to quantify the total flavonoid content.

Result: This study gave positive results on the qualitative test of phenolics and flavonoids. Meanwhile, the fraction assay results showed total phenolic levels of $45.19 \mu \mathrm{gGAE} / \mathrm{mg}$ and total flavonoid levels of 165.06 $\mu \mathrm{gQE} / \mathrm{mg}$.

Conclusion: The n-hexane fraction of $M$. caesia leaves methanol extracts contains phenols and flavonoid content so that it has the potential as a medicinal plant.
\end{abstract}

Keywords: Binjai leaves, methanol extracts, $n$-hexane fraction, phenol, flavonoid.

\section{Intisari}

Latar belakang: Daun binjai (Mangifera caesia Jack. ex. Wall) memiliki senyawa fenolik dan flavonoid yang penting dalam pengembangan tanaman obat. Perbedaan pelarut dan fraksinasi akan memberikan kadar senyawa aktif yang berbeda.

Tujuan: Penelitian ini bertujuan untuk mengetahui secara kualitatif dan kuantitatif senyawa fenolik dan flavonoid dari fraksi n-heksan ekstrak metanol daun binjai.

Metode: Metode soxhletasi dengan pelarut metanol digunakan untuk mengekstraksi daun binjai yang dilanjutikan dengan fraksinasi. Kromatografi Lapis Tipis (KLT) yang dilanjutkan dengan reagen semprot digunakan untuk menguji senyawa fenolik dan flavonoid. Reagen Folin-Ciocalteu digunakan untuk menetapkan kadar total fenolik, sedangkan pereaksi $\mathrm{AlCl}_{3}$ untuk menetapkan kadar total flavonoid.

Hasil: Penelitian ini memberikan hasil positif pada uji kualitatif fenolik dan flavonoid, sedangkan hasil penetapan kadar fraksi memberikan hasil total fenolik sebesar 45,19 $\mu \mathrm{gGAE} / \mathrm{mg}$ dan kadar total flavonoid $165,06 \mu \mathrm{gQE} / \mathrm{mg}$.

Kesimpulan: Fraksi n-heksana ekstrak metanol daun M. caesia memiliki kandungan fenolik dan flavonoid sehingga berpotensi untuk dikembangkan sebagai tanaman obat,

Kata Kunci: Daun binjai, ekstrak metanol, fraksi n-heksan, fenolik, flavonoid.

\section{Pendahuluan}

Senyawa fenolik adalah kelompok produk alami yang terdapat dalam buah-buahan, sayuran, dan minuman. Golongan senyawa tersebut disintesis oleh tanaman dan menunjukkan banyak efek penting seperti perlindungan terhadap patogen dan memainkan peran utama sebagai antioksidan dan antikarsinogenik potensial (Cefali et al., 2019). Genus Mangifera merupakan 
salah satu genus yang pada penelitian sebelumnya terbukti mempunyai kandungan senyawa fenolik dan flavonoid (Salahuddin et al., 2016).

Salah satu anggota genus Mangifera yaitu daun binjai (M. caesia Jack. Ex. Wall) terbukti memiliki senyawa fenolik dan flavonoid, sehingga memiliki potensi sebagai tanaman obat (Adham et al., 2019; Ismail et al., 2019). Ekstrak metanol daun binjai dilaporkan memiliki kadar total flavonoid $738 \mu \mathrm{gQE} / \mathrm{mg}$ dan total fenolik 559 gGAE/mg ekstrak (Ramadhan, Hipmi, et al., 2020). Hasil ini lebih tinggi dibandingkan bagian buahnya yaitu 0,019 $\mu \mathrm{gTAE} / \mathrm{mg}$ fraksi (Paulinus et al., 2015). Selain itu, metode fraksinasi juga akan memberikan hasil yang berbeda dengan total fenolik akan lebih tinggi pada fraksi air, sedangkan total flavonoid lebih tinggi pada fraksi etil asetat (Ramadhan, Sayakti, et al., 2020).

Pada penelitian yang lain menunjukkan bahwa penggunaan pelarut n-heksan meningkatkan perolehan flavonoid dibandingkan dengan pelarut etanol baik dengan metode maserasi maupun soxhletasi (Rosita et al., 2017). Dengan demikian, penelitian ini berupaya untuk menganalisis kualitatif dan kuantitatif kandungan fenolik dan flavonoid hasil fraksinasi dengan nheksan dari ekstrak metanol daun M. caesia yang diuji.

\section{Metode}

\subsection{Alat}

Peralatan pada penelitian ini yaitu seperangkat soxhlet $\left(\right.$ Pyrex $\left.^{\circledR}\right)$ beserta alat gelas lainnya, selain itu juga corong pisah (Pyrex $\left.{ }^{\circledR}\right)$, neraca analitik (Fujitsu ${ }^{\circledR}$ ), rotary evaporator (IKFR 10 ${ }^{\circledR}$ ), penangas air $\left(\right.$ Memmert $\left.^{\circledR}\right)$, mikropipet (Dragon Lab $^{\circledR}$ ), Vortex (Bionex ${ }^{\circledR}$ ), dan pengukuran absorbansi menggunakan spektrofotometer UV-Vis ( $P G$ Instruments-T60 ${ }^{\circledR}$ ).

\subsection{Bahan}

Bahan yang digunakan yaitu daun binjai, $\mathrm{AlCl}_{3}\left(\operatorname{Merck}^{\circledR}\right.$, Germany), asam asetat $\left(\operatorname{Merck}^{\circledR}\right.$,

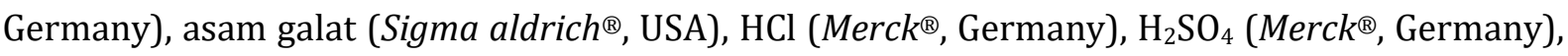

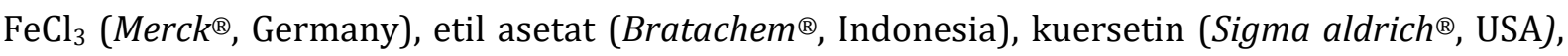
metanol (Merck ${ }^{\circledR}$, Germany), metanol teknis (Bratachem ${ }^{\circledR}$, Indonesia), n-heksana (Bratachem ${ }^{\circledR}$, Indonesia), $\mathrm{NaOH}\left(\right.$ Merck $^{\circledR}$, Germany), $\mathrm{Na}_{2} \mathrm{CO}_{3}$ (Merck ${ }^{\circledR}$, Germany), reagen Folin-ciocalteu (Merck ${ }^{\circledR}$, Germany), akuades (Onemed ${ }^{\circledR}$, Indonesia), $\mathrm{Pb}\left(\mathrm{CH}_{3} \mathrm{COOH}\right)_{2}\left(\right.$ Merck $^{\circledR}$, Germany), plat silika gel $\mathrm{GF}_{254}$ (Merck ${ }^{\circledR}$, Germany).

\subsection{Metode}

\subsubsection{Pengambilan sampel daun binjai}

Spesimen daun binjai dikumpulkan pada November 2019 dari Kelurahan Guntung Manggis, Banjarbaru, Kalimantan Selatan dan dideterminasi oleh Laboratorium Dasar Fakultas Matematika dan Ilmu Pengetahuan Alam (FMIPA) Universitas Lambung Mangkurat sebagai 
Mangifera caesia Jack. Ex. Wall. Sampel daun binjai yang diambil merupakan daun binjai yang matang atau daun keempat dari pucuk sampai daun kelima dari pangkal (Dwidhanti et al., 2018).

\subsubsection{Pengolahan simplisia daun binjai}

Sampel daun M. caesia yang telah dikumpulkan, disortasi basah, dicuci, dan selanjutnya daun dipotong hingga kecil, kemudian dikeringkan di dalam ruangan yang bebas dari sinar matahari langsung. Setelah diperoleh simplisia kering, dilakukan penyerbukan, kemudian diayak hingga halus dengan pengayakan mesh 40 (Khairiah et al., 2018).

\subsubsection{Pembuatan ekstrak metanol daun binjai}

Ekstraksi daun M. caesia dengan metanol menggunakan soxhlet dengan perbandingan 1:5 (simplisia:pelarut) pada suhu pemanasan $60^{\circ} \mathrm{C}$. Ekstrak kental diperoleh dengan rotary evaporator $50^{\circ} \mathrm{C}$ yang dilanjutkan dengan penangas air hingga diperoleh bobot tetap (Rosita et al., 2017; Shinde \& Chavan, 2014).

\subsubsection{Fraksinasi ekstrak metanol daun binjai}

Fraksinasi dilakukan dengan melarutkan ekstrak dalam akuades perbandingan 1:2, kemudian ditambahkan $50 \mathrm{~mL}$ n-heksan, digojog sampai dua lapisan dan dipisahkan. Proses ini diulang menggunakan n-heksan dengan jumlah yang sama sampai diperoleh fase n-heksan jernih. Fraksi n-heksan dipekatkan dengan penangas air hingga diperoleh bobot tetap (Khairiah et al., 2018).

\subsubsection{Skrinning Fitokimia}

a. Identifikasi fenolik

Sampel 0,1\% (b/v) dilarutkan dalam metanol, diambil $1 \mathrm{~mL}$ dan ditambahkan dengan reagen $\mathrm{FeCl}_{3}$ 5\% sebanyak $1 \mathrm{~mL}$. Warna hijau kehitaman, merah, ungu, biru, hitam pekat, dan endapan hitam menunjukkan kandungan fenolik di dalam sampel (Ramadhan et al., 2021; Setiabudi, 2017).

b. Identifikasi flavonoid

Larutan sampel 0,1\% (b/v) dalam metanol dibagi menjadi 3 tabung sebanyak $1 \mathrm{~mL}$. Sampel dinyatakan mengandung flavonoid jika setelah ditambahkan beberapa tetes $\mathrm{NaOH} 10 \%$ muncul warna kuning yang memudar setelah ditambahkan $\mathrm{HCl} 2 \mathrm{~N}$ (Ramadhan et al., 2021). Pengujian kedua ditambah $1 \mathrm{~mL} \mathrm{~Pb}\left(\mathrm{C}_{2} \mathrm{H}_{3} \mathrm{O}_{2}\right)_{2}$ 10\% akan muncul warna coklat kekuningan (Khairiah et al., 2018). Pengujian ketiga ditambah serbuk $\mathrm{Mg}$ dan $\mathrm{HCl}$ pekat $1 \mathrm{~mL}$ akan muncul warna kuning, jingga, merah dan hijau (Fitriyanti et al., 2020).

\subsubsection{Identifikasi fenolik dan flavonoid dengan kromatografi lapis tipis}

Hasil fraksinasi konsentrasi 0,2\% dalam metanol ditotolkan pada plat KLT silica gel $\mathrm{GF}_{254}$ dan eluen etil asetat : n-heksan (3:1). Pengamatan spot KLT pada UV $254 \mathrm{~nm}$ dan $366 \mathrm{~nm}$. Kemudian dilanjutkan dengan penyemprotan $\mathrm{FeCl}_{3} 10 \%$ untuk identifikasi fenolik dan $\mathrm{AlCl}_{3} 5 \%$ untuk identifikasi flavonoid. Jika setelah disemprot $\mathrm{FeCl}_{3} 10 \%$ noda berubah menjadi hitam 
menunjukkan kandungan fenolik (Marliani et al., 2016). Jika noda berubah menjadi kuning setelah di semprot $\mathrm{AlCl}_{3}$ 5\% menunjukkan positif mengandung flavonoid (Sopiah et al., 2019).

\subsubsection{Penetapan kadar total fenolik}

Pertama, dilakukan penetapan panjang gelombang $(\lambda)$ maksimal, yaitu $0,6 \mathrm{~mL}$ asam galat 100 ppm ditambahkan $1 \mathrm{~mL}$ reagen Folin-Ciocalteu dan didiamkan 5 menit, kemudian dilakukan penambahan $2 \mathrm{~mL} \mathrm{Na}_{2} \mathrm{CO}_{3} 10 \%$ dan dihomogenkan. Setelah didiamkan pada ruang gelap selama 70 menit, absorbansi ditetapkan dengan spektrofotometri UV-Vis dan didapatkan $\lambda$ maksimal 734 $\mathrm{nm}$. Seri kadar senyawa standar asam galat 6, 12, 18, 24, dan 30 ppm digunakan untuk pembuatan kurva baku. Penentuan absorbansi seri kadar dan fraksi n-heksan dilakukan dengan cara yang sama dengan penetapan panjang gelombang maksimal. Regresi linear kurva standar digunakan untuk perhitungan kadar total fenolik pada fraksi n-heksan yang diekspresikan sebagai $\mu g$ gallic acid equivalent (GAE) per mg serbuk ekstrak kering ( $\mu \mathrm{gGAE} / \mathrm{mg}$ ) dan dihitung menggunakan rumus sebagai berikut (Ramadhan, Hipmi, et al., 2020; Ramadhan et al., 2021):

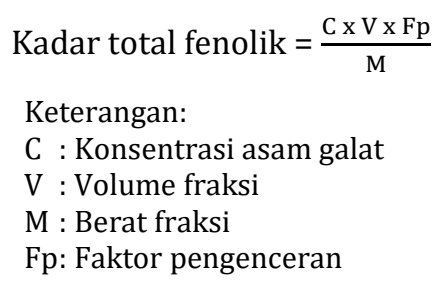

\subsubsection{Penetapan kadar total flavonoid}

Langkah pertama yang dilakukan adalah penentuan $\lambda$ maksimal dengan $1 \mathrm{~mL}$ senyawa standar kuersetin 100 ppm yang ditambah $1 \mathrm{~mL} \mathrm{AlCl} \mathrm{Al}_{3}$ 10\% dan $8 \mathrm{~mL}$ asam asetat 5\%. Setelah didiamkan 8-24 menit, scanning panjang gelombang dilakukan dengan spektrofotometri UV-Vis dan diperoleh $\lambda$ maksimal $415 \mathrm{~nm}$. Seri kadar standar kuersetin 20, 40, 60, 80, dan 100 ppm disiapkan dan digunakan untuk pembuatan kurva baku. Persiapan seri kadar dan fraksi n-heksan dilakukan dengan cara sama dengan penetapan panjang gelombang maksimal dan diukur absorbansinya pada panjang gelombang $415 \mathrm{~nm}$ (Ramadhan, Sayakti, et al., 2020; Sukmawati et al., 2018). Kadar total flavonoid fraksi n-heksan dihitung dengan menggunakan regresi linear kurva standar dan diekspresikan sebagai quercetin equivalent $(\mu \mathrm{g} Q E / \mathrm{mg})$ yang dihitung dengan rumus berikut (Ramadhan et al., 2021):

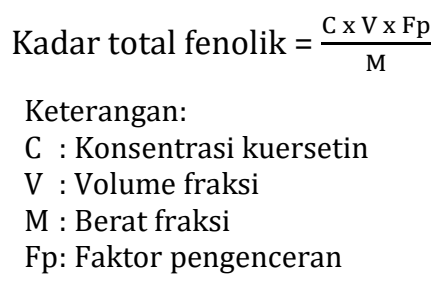

\section{Hasil dan pembahasan}

Ekstrak metanol daun M. caesia diperoleh dengan metode soxhletasi karena metode ini menggunakan titik didih pelarut sehingga menurunkan tegangan permukaan dan viskositas 
pelarut. Hal tersebut menyebabkan peningkatan efisiensi penetrasi pelarut ke bagian aktif matriks simplisia, sehingga meningkatkan kelarutan senyawa yang diekstraksi sehingga lebih optimal dalam memperoleh flavonoid (Ramadhan, Hipmi, et al., 2020; Rosita et al., 2017).

Metanol sebagai pelarut memiliki keunggulan titik didih cukup rendah sehingga mempermudah pemisahannya, terlebih flavonoid mampu larut dalam metanol (Tanaya et al., 2015). Penelitian Ramadhan et al. (2020)menguatkan pernyataan tersebut karena hasil total fenolik dan flavonoid dengan metode soxhletasi metanol lebih tinggi dari penelitian Rosita et al. (2017) yang menggunakan etanol dengan metode yang sama.

Proses fraksinasi menggunakan pelarut organik dengan polaritas yang berbeda, untuk memisahkan komponen ekstrak berdasarkan tingkat kepolaran memberikan pemisahan yang lebih baik terutama untuk ekstrak yang memiliki golongan fenolik dan flavonoid yang berbedabeda (Ramadhan et al., 2021). Proses fraksinasi dimulai dengan n-heksan sebagai pelarut non polar, dilanjutkan penambahan air yang berperan sebagai pelarut polar. Fraksinasi dimulai dengan pelarut non polar agar proses pengikatan senyawa bertahap (Rahayu et al., 2015). Hasil rendemen fraksi n-heksan pada penelitian ini sebesar 4,46\%. Hasil tersebut menunjukkan rendemen yang lebih kecil jika dibandingkan dengan fraksi air (11,68\%), akan tetapi lebih besar dari fraksi etil asetat (3,6\%) ekstrak metanol (Rauf, 2020; Ulya, 2020).

Hasil skrinning fitokimia fraksi n-heksan ekstrak metanol daun M. caesia menunjukkan positif mengandung fenolik dan flavonoid (Tabel 1). Kandungan fenolik dan flavonoid memiliki peranan penting dalam menghasilkan aktivitas biologis. Genus Mangifera khususnya M. indica (Mangga) terkenal dengan kandungan fitokimia utama golongan fenolik yaitu mangiferin. Senyawa ini merupakan glikosida xanton yang memiliki banyak sifat bioaktif potensial seperti antidiabetes, antiinflamasi, antioksidan, antitumor, antivirus dan sebagai imunomodulator (Shinde \& Chavan, 2014). Flavonoid juga merupakan sekelompok besar senyawa polifenolik yang memiliki struktur benzo- $\gamma$-piron dan banyak terkandung dalam tanaman. Flavonoid juga banyak bertanggung jawab atas berbagai aktivitas farmakologis. Khasiat yang banyak dihasilkan oleh flavonoid yaitu sebagai antibakteri, hepatoprotektif, antiinflamasi, antikanker, dan agen antivirus. Potensi ini dapat menjadikan flavonoid sebagai basis agen farmasi untuk pengobatan banyak penyakit menular dan penyakit degeneratif (Kumar \& Pandey, 2013).

Tabel 1. Hasil skrining fitokimia fraksi n-heksan ekstrak metanol daun M. caesia

\begin{tabular}{|c|c|c|c|}
\hline $\begin{array}{l}\text { Metabolit } \\
\text { Sekunder }\end{array}$ & Pereaksi & Pengamatan & Hasil \\
\hline Fenolik & $\mathrm{FeCl}_{3} 5 \%$ & Terbentuk endapan hitam & $(+)$ \\
\hline \multirow[t]{2}{*}{ Flavonoid } & $\mathrm{NaOH} 10 \%+\mathrm{HCl}$ & $\begin{array}{l}\text { Terbentuk warna kuning setelah ditambah } \\
\text { pereaksi } \mathrm{NaOH} \text {, memudar setelah } \\
\text { penambahan } \mathrm{HCl}\end{array}$ & $(+)$ \\
\hline & $\begin{array}{l}\mathrm{Pb}\left(\mathrm{CH}_{3} \mathrm{COOH}\right)_{2} 10 \% \\
\mathrm{Mg}+\mathrm{HCl}\end{array}$ & $\begin{array}{l}\text { Tidak terbentuk warna coklat kekuningan } \\
\text { Terbentuk warna kuning kehijauan }\end{array}$ & $\begin{array}{l}-(-1) \\
(-) \\
(+)\end{array}$ \\
\hline
\end{tabular}


Uji kualiatif fraksi n-heksan ekstrak metanol daun binjai dengan metode KLT yang dilanjutkan dengan penyemprotan $\mathrm{FeCl}_{3} 10 \%$ menunjukkan kandungan fenolik yang ditunjukkan dengan warna biru kehitaman pada nilai Rf: 0,083; 0,15; dan 0,41 (Gambar 1). Selain itu, terbentuk warna kekuningan setelah disemprot menggunakan $\mathrm{AlCl}_{3} 5 \%$ yang menunjukkan keberadaan flavonoid pada nilai Rf: 0,083; 0,15; 0,60 (Gambar 2).

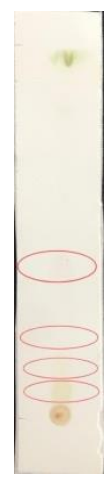

a

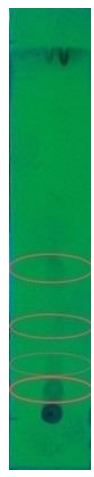

$\mathrm{b}$

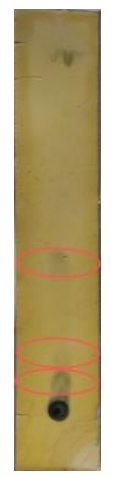

C

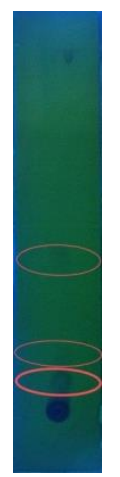

d

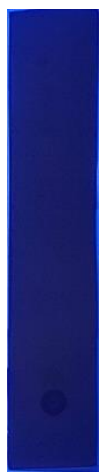

$\mathrm{e}$

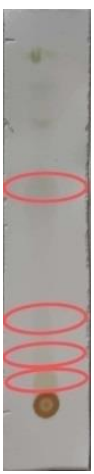

a

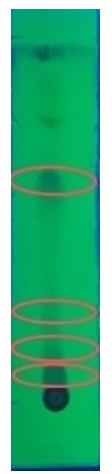

b

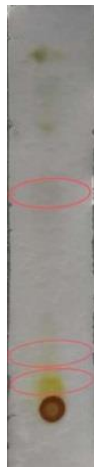

C

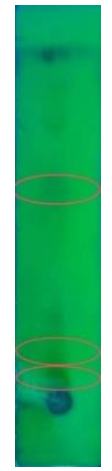

d

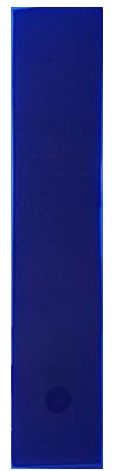

e
Gambar 1. Hasil identifikasi senyawa fenolik (a) Secara visual (b) Pengamatan sinar UV $254 \mathrm{~nm}$ (c) Secara visual setelah penyemprotan $\mathrm{FeCl}_{3}$ (d) Pengamatan sinar UV $254 \mathrm{~nm}$ setelah disemprot $\mathrm{FeCl}_{3}$ (e) Pengamatan sinar UV $366 \mathrm{~nm}$ setelah disemprot $\mathrm{FeCl}_{3}$
Gambar 2. Hasil identifikasi senyawa flavonoid (a) Secara visual (b) Pengamatan sinar UV $254 \mathrm{~nm}$ (c) Secara visual setelah disemprot $\mathrm{AlCl}_{3}$ (d) Pengamatan sinar UV $254 \mathrm{~nm}$ setelah disemprot $\mathrm{AlCl}_{3}$ (e) Pengamatan sinar UV $366 \mathrm{~nm}$ setelah disemprot $\mathrm{AlCl}_{3}$

Metode kolorimetri Folin-Ciocalteu digunakan untuk menetapkan kadar total fenolik fraksi n-heksan dari ekstrak metanol daun M. Caesia (Ramadhan et al., 2021) dengan menggunakan asam galat sebagai senyawa standar karena sifatnya yang stabil dan termasuk asam fenolik sederhana (Ahmad et al., 2015). Perubahan warna kuning menjadi biru setelah ditambahkan larutan $\mathrm{Na}_{2} \mathrm{CO}_{3}$ menunjukkan hasil yang positif terdapat kandungan fenolik dalam sampel uji (Ramadhan et al., 2021).

Pada panjang gelombang maksimum $734 \mathrm{~nm}$ seri kadar asam galat memberikan persamaan regresi linear $y=0,0221 x+0,1105$ dan nilai koefisien korelasi $(r) 0,997$. Hasil penetapan kadar total fenolik fraksi n-heksan ekstrak metanol daun M. caesia menunjukkan terdapat 45,2 $\mu \mathrm{gGAE} / \mathrm{mg}$ fraksi atau 4,5\% (Tabel 2). Hasil ini lebih kecil dari fraksi air yaitu $782 \mu \mathrm{gGAE} / \mathrm{mg}$ fraksi (Rauf, 2020) dan juga fraksi etil asetat ekstrak metanol 430 $\mu \mathrm{gGAE} / \mathrm{mg}$ fraksi (Ulya, 2020). Hal ini dikarenakan sifat senyawa fenolik yang cenderung polar, sehingga kelarutan senyawa fenolik pada bagian non polar seperti n-heksan biasanya lebih rendah (Ramadhan et al., 2021). Namun demikian, fraksi n-heksan ekstrak metanol daun M. caesia masih berpotensi untuk diteliti lebih dalam karena kadar total fenolik yang terkandung masih lebih tinggi jika dibandingkan dengan kadar total fenolik fraksi etil asetat buah binjai pada penelitian Paulinus et al. (2015) yaitu 19,52 $\mu \mathrm{gTAE} / \mathrm{mg}$ fraksi. 
17 | Yuliani, C. R. dkk /Jurnal Ilmiah Farmasi (Scientific Journal of Pharmacy) Special Edition 2022. 11-19

Tabel 2. Hasil perhitungan kadar fenolik total

\begin{tabular}{lccc}
\hline \multicolumn{1}{c}{ Sampel } & $\begin{array}{c}\text { Absorbansi } \\
\text { Sampel }\end{array}$ & $\begin{array}{c}\text { Gallic acid equivalent/GAE } \\
(\mathbf{\% b} / \mathbf{b})\end{array}$ & $\begin{array}{c}\text { Rata-rata GAE } \mathbf{\text { SD }} \\
\text { (\%)/b) }\end{array}$ \\
\hline \multirow{2}{*}{ Fraksi n-heksan daun } & 0,606 & 4,48 & \\
binjai 500 ppm & 0,608 & 4,50 & $4,52 \pm 0,04$ \\
& 0,638 & 4,57 & \\
\hline
\end{tabular}

Metode kolorimetri dengan pereaksi kompleks $\mathrm{AlCl}_{3}$ digunakan untuk menetapkan kadar total flavonoid fraksi n-heksan ekstrak metanol daun M. caesia dengan kuersetin sebagai senyawa standar (Ramadhan et al., 2021). Pembentukan warna kuning sebagai indikator positif terjadi karena terbentuk kompleks antara $\mathrm{AlCl}_{3}$ dan gugus ortohidroksil pada cincin A atau B flavonoid yang distabilkan dengan penambahan asam asetat (Ahmad et al., 2015).

Tabel 3. Hasil perhitungan kadar total flavonoid

\begin{tabular}{lccc}
\hline \multicolumn{1}{c}{ Sampel } & $\begin{array}{c}\text { Absorbansi } \\
\text { Sampel }\end{array}$ & $\begin{array}{c}\text { Quercetin equivalent/QE } \\
\mathbf{( \% ) / b )}\end{array}$ & $\begin{array}{c}\text { Rata-rata QE } \pm \text { SD } \\
\text { (\%b/b) }\end{array}$ \\
\hline Fraksi n-heksan daun & 0,666 & 16,64 & \\
binjai 500 ppm & 0,649 & 16,26 & $16,51 \pm 0,17$ \\
& 0,665 & 16,62 & \\
\hline
\end{tabular}

Seri kadar kurva baku kuersetin yang diuji pada panjang gelombang $415 \mathrm{~nm}$ menghasilkan persamaan regresi linear $y=0,0089 x-0,0745$ dan nilai koefisien korelasi $(r)$ 0,9978. Hasil perhitungan kadar total flavonoid pada fraksi memberikan hasil 165,06 $\mu g Q E / m g$ fraksi atau 16,51\% (Tabel 3). Kadar ini lebih kecil jika dibandingkan dengan fraksi etil asetat yaitu 274,32 $\mu \mathrm{gQE} / \mathrm{mg}$ fraksi (Ulya, 2020), namun lebih tinggi dari fraksi airnya yaitu 118,8 $\mu \mathrm{gQE} / \mathrm{mg}$ fraksi (Rauf, 2020). Perbedaan hasil ini dapat disebabkan sifat senyawa flavonoid yang terkandung pada daun binjai memiliki polaritas yang beragam dan lebih banyak bersifat semi polar, seperti yang disebutkan oleh Kumar \& Pandey (2013) bahwa berbagai flavonoid yang ditemukan di alam memiliki sifat fisik, kimia, dan fisiologis yang berbeda satu sama lain. Namun demikian, kadar flavonoid pada M. caesia ini masih lebih besar jika dibandingkan dengan spesies Mangifera lain, misalnya pada penelitian Bakti et al. (2017) dengan kadar total flavonoid ekstrak etanol daun kasturi (Mangifera casturi Kosterm.) sebesar 0,093 $\mu \mathrm{gQE} / \mathrm{mg}$ ekstrak (9,3\%). Serta pada penelitian kulit batang kasturi, Ramadhan et al. (2021) melaporkan kadar total flavonoid fraksi etil asetat ekstrak metanolnya sebesar 5,15 $\mu \mathrm{gQE} / \mathrm{mg}$ fraksi. 
18 | Yuliani, C. R. dkk /Jurnal Ilmiah Farmasi (Scientific Journal of Pharmacy) Special Edition 2022. 11-19

\section{Kesimpulan}

Fraksi n-heksan ekstrak metanol daun Mangifera caesia Jack. ex. Wall memiliki kadar total fenolik 45,19 $\mu \mathrm{g} G A E / \mathrm{mg}$ dan flavonoid 165,06 $\mu \mathrm{g} Q E / \mathrm{mg}$. Oleh karena itu, fraksi ini berpotensi ditelusuri lebih lanjut dan dikembangkan sebagai obat tradisional.

\section{Ucapan terima kasih}

Penelitian ini memperoleh pendanaan melalui Hibah Penelitian Dosen Pemula Tahun Anggaran 2020 yang diselenggarakan oleh Kementerian Riset, Teknologi, dan Pendidikan Tinggi (KEMENRISTEK DIKTI) Republik Indonesia.

\section{Daftar pustaka}

Adham, D., Taufiqurrahman, I., \& Helmi, Z. N. (2019). Flavonoid Level Analysis of Binjai Leaf Extract (Mangifera caesia) in Ethanol, Methanol, and n-Hexane Solvents. Dentino: Jurnal Kedokteran Gigi, 4(1), 46-49.

Ahmad, A., Juwita, J., \& Ratulangi, S. (2015). Penetapan Kadar Fenolikik dan Flavonoid Total Ekstrak Metanol Buah dan Daun Patikala (Etlingera elatior (Jack) R.M.SM). Pharmaceutical Sciences and Research, 2, 1-10. doi:10.7454/psr.v2i1.3481

Bakti, A. A., Triyasmono, L., \& Rizki, M. I. (2017). Penentuan Kadar Flavonoid Total dan Uji Antioksidan Ekstrak Etanol Daun Kasturi (Mangifera casturi Kosterm.) dengan Metode DPPH. Jurnal Pharmascience, 4 102-108. doi:http://dx.doi.org/10.20527/jps.v4i1.5762

Cefali, L. C., Ataide, J. A., Fernandes, A. R., Sousa, I. M. O., Gonçalves, F., Eberlin, S., Dávila, J. L., Jozala, A. F., Chaud, M. V., Sanchez-Lopez, E., Marto, J., d'Ávila, M. A., Ribeiro, H. M., Foglio, M. A., Souto, E. B., \& Mazzola, P. G. (2019). Flavonoid-Enriched Plant-ExtractLoaded Emulsion: A Novel Phytocosmetic Sunscreen Formulation with Antioxidant Properties. Antioxidants (Basel), 8(10). doi:10.3390/antiox8100443

Dwidhanti, F., Taufiqurrahman, I., \& Sukmana, B. i. (2018). Cytotoxicity Test of Binjai Leaf (Mangifera caesia) Ethanol Extract in Relation to Vero Cells. Dental Journal (Majalah Kedokteran Gigi), 51, 108. doi:10.20473/j.djmkg.v51.i3.p108-113

Fitriyanti, F., Norhavid, M. F. R., \& Ramadhan, H. (2020). Uji Daya Hambat Ekstrak Etanol 70\% Biji Pepaya (Carica papaya L.) terhadap Bakteri Propionibacterium acnes Penyebab Jerawat. Pharmacoscript, 3(2), 144-149. doi:https://doi.org/10.36423/pharmacoscript.v3i2.400

Ismail, N. A., Bakar, M. F. A., Bakar, F. I. A., Rahim, A. C., \& Murdin, N. ( 2019). Underutilized Mangifera Species (Mangifera caesia, Mangifera quadrifida and Mangifera odorata) from Borneo: A Potential Source of Natural Antioxidant. Journal of Engineering and Applied Sciences, 14(4), 1169-1177. doi:http://dx.doi.org/10.36478/jeasci.2019.1169.1177

Khairiah, K., Taufiqurrahman, I., \& Putri, D. K. T. (2018). Antioxidant Activity Test of Ethyl Acetate Fraction of Binjai (Mangifera caesia) Leaf Ethanol Extract. Dental Journal (Majalah Kedokteran Gigi), 51(4), 164-168. doi:http://dx.doi.org/10.20473/j.djmkg.v51.i4.p164-168

Kumar, S., \& Pandey, A. K. (2013). Chemistry and Biological Activities of Flavonoids: An Overview. Scientific World Journal, 2013, 162750. doi:10.1155/2013/162750

Marliani, L., Naimah, A., \& Roni, A. (2016). Penetapan Kadar Fenolikat Total dan Flavonoid Total Ekstrak Etanol Daun, Kulit Batang dan Kulit Buah Kasturi (Mangifera casturi). 
19 | Yuliani, C. R. dkk /Jurnal Ilmiah Farmasi (Scientific Journal of Pharmacy) Special Edition 2022. 11-19

Proceeding of Mulawarman Pharmaceuticals Conferences, 3, 275-281. doi:https://doi.org/10.25026/mpc.v3i2.121

Paulinus, Y. V. G., Jayuska, A., Ardiningsih, P., \& Nofiani, R. (2015). Aktivitas Antioksidan dan Kandungan Total Fenolik Fraksi Etil Asetat Buah Palasu (Mangifera caesia Jack). Jurnal Kimia Khatulistiwa, 4(1), 47-50.

Rahayu, S., Kurniasih, N., \& Amalia, V. (2015). Ekstraksi dan Identifikasi Senyawa Flavonoid dari Limbah Kulit Bawang Merah sebagai Antioksidan Alami. al-Kimiya, 2, 1-8. doi:10.15575/ak.v2i1.345

Ramadhan, H., Hipmi, A. F., \& Sayakti, P. I. (2020). Antioxidant Activity of Binjai Leaves (Mangifera caesia Jack. Ex. Wall) Methanol Extract from South Kalimantan using DPPH and CUPRAC Methods. Paper presented at the The 1st ITB International Conference on Pharmaceutical Sciences and Pharmacy Bandung.

Ramadhan, H., Sayakti, P. I., Ulya, R., Hidayati, M. P., Z.P, \& Rauf, A. (2020). Phenol-Flavonoid Contents and Antioxidant Activity of Ethyl Acetate Fraction and Aqueous Fraction of Binjai (Mangifera caesia Jack. Ex. Wall) Leaves Methanol Extract from South Kalimantan. Paper presented at the 3rd Joint Conference UNAIR-USM International Conference of Pharmacy and Health Sciences 2020, Surabaya.

Ramadhan, H. Q., Rezky, D. P., \& Susiani, E. F. (2021). Penetapan Kandungan Total FenolikikFlavonoid pada Fraksi Etil Asetat Kulit Batang Kasturi (Mangifera casturi Kosterman). Jurnal Farmasi dan Ilmu Kefarmasian Indonesia, 8 (1), 58-67.

Rauf, A. (2020). Penetapan Kadar Total Fenolik dan Flavonoid Fraksi Air dari Ekstrak Metanol Daun Binjai (Mangifera Caesia Jack. Ex. Wall.) menggunakan Metode Spektrofotometri Uv-Vis. (Bachelor). STIKES Borneo Lestari, Banjarbaru.

Rosita, J. M., Taufiqurrahman, I., \& Edyson, E. (2017). Perbedaan Total Flavonoid Antara Metode Maserasi dengan Sokletasi pada Ekstrak Daun Binjai (Mangifera caesia) (Studi Pendahuluan terhadap Proses Pembuatan Sediaan Obat Penyembuhan Luka). Dentino Jurnal Kedokteran Gigi, 1 100-105.

Salahuddin, M. A. H., Idris, S., \& Mirad, R. (2016). Natural Antioxidant Properties of Selected Wild Mangifera Species in Malaysia. Journal of Tropical Agriculture and Food Science, 44, 63-72.

Setiabudi, D. A. (2017). Uji Skrining Fitokimia Metanol Kulit Batang Tumbuhan Klampok Watu (Syzygium litorale). UNESA Journal of Chemstry, 6(3), 155-160.

Shinde, S. S., \& Chavan, A. R. (2014). Isolation of Mangiferin from Different Varieties of Mangifera Indica Dried Leaves. International Journal of Scientific \& Engineering Research, 928-934(5), 6.

Sopiah, B., Muliasari, H., \& Yuanita, E. (2019). Skrining Fitokimia dan Potensi Aktivitas Antioksidan Ekstrak Etanol Daun Hijau dan Daun Merah Kastuba. Jurnal Ilmu Kefarmasian Indonesia, 17(1), 27-33.

Sukmawati, S., Sudewi, S., \& Pontoh, J. (2018). Optimasi dan Validasi Metode Analisis dalam Penentuan Kandungan Total Flavonoid pada Ekstrak Daun Gedi Hijau (Abelmoscus manihot L.) yang diukur Menggunakan Spektrofotometer UV-Vis. PHARMACON, $7(3), 32-41$.

Tanaya, V., Retnowati, R., \& Suratmo, S. (2015). Fraksi Semi Polar dari Daun Mangga Kasturi (Mangifera Casturi Kosterm). Jurnal Ilmu Kimia Universitas Brawijaya, 1(1), 778784.

Ulya, R. (2020). Penetapan Kadar Total Fenolik dan Flavonoid Fraksi Etil Asetat dari Ekstrak Metanol Daun Binjai (Mangifera Caesia Jack. Ex. Wall.) menggunakan Spektrofotometri Uv-Vis. (Bachelor). STIKES Borneo Lestari, Banjarbaru. 